\title{
Simulation of soil water balance and partitioning of evapotranspiration of maize grown in two growing seasons in Southern Brazil
}

\author{
Viviane Schons de Ávila ${ }^{*}$ Mirta Teresinha Petry ${ }^{1}$ Reimar Carlesso $^{1}$ Juliano Dalcin Martins ${ }^{2}$ \\ María Gabriela González ${ }^{3}$ Zanandra Boff de Oliveira ${ }^{4}$ \\ José Nilton Vieira Nunes ${ }^{1}$ Sônia Thais Menegaz ${ }^{1}$
}

${ }^{1}$ Departamento de Engenharia Rural, Universidade Federal de Santa Maria (UFSM), Camobi, 97105-900, Santa Maria, RS, Brasil. E-mail: vivideavila@gmail.com. "Corresponding author.

${ }^{2}$ Instituto Federal de Educação, Ciência e Tecnologia do Rio Grande do Sul (IFRS), Campus Ibirubá, Bairro Esperança, Ibirubá, RS, Brasil. ${ }^{3}$ Faculdade de Agronomia, Universidade Central da Venezuela, Ciudad Universitaria, Los Chaguaramos, Caracas, Venezuela.

${ }^{4}$ Universidade Federal de Santa Maria, Campus de Cachoeira do Sul, Cachoeira do Sul, RS, Brasil.

\begin{abstract}
The objective of this study was to simulate the variation of the available soil water during maize crop growth, in two different sowing times (first and second growing season), using a drip irrigation system. The treatments consisted of different irrigation strategies (full to deficit). The SIMDualKc simulation model was used to determine the daily soil water balance and crop evapotranspiration using the dual crop coefficient approach. Soil, climate, crop and irrigation parameters were used as input data. Two experiments were carried out in a rainout shelter composed of two metallic structures (16x10m) in the city of Santa Maria, Rio Grande do Sul, Brazil, during 2010/11 (second crop, season 1) and 2011/12 (first crop, season 2) growing seasons, under no-tillage system. The simulations showed that all the irrigation management strategies used in season 2 resulted in soil water deficit, while only two strategies showed deficit in season 1. Results showed good agreement between observed and simulated soil water data, with an $R^{2}$ ranging from 0.86 to 0.99 and the root mean square error ranging from 2.7 to $5.6 \%$ of the total available water for seasons 1 and 2, respectively. The observed results of water balance showed that maize grown in season 2 presented higher water consumption compared to season 1, due to the higher atmospheric demand of season 2. The SIMDualKc model allowed the partitioning of crop evapotranspiration into soil evaporation and crop transpiration, demonstrating that the vegetative growth subperiod presented the greatest differences between the two seasons compared to the others growth phases.

Key words: SIMDualKc, dual coefficient, evapotranspiration partitioning, soil evaporation, crop transpiration.
\end{abstract}

Simulação do balanço hídrico do solo e particionamento da evapotranspiração do milho cultivado em duas épocas de semeadura no Sul do Brasil

RESUMO: O objetivo deste estudo foi simular a variação da água disponível no solo durante o desenvolvimento da cultura do milho, em duas épocas de semeadura diferentes (primeira e segunda safra), utilizando sistema de irrigação por gotejamento. Os tratamentos consistiram em diferentes estratégias de irrigação (plena e deficitária). O modelo de simulação SIMDualKc foi utilizado para determinar o balanço hídrico diário do solo e a evapotranspiração da cultura usando a abordagem do coeficiente cultura dual. Os parâmetros de solo, clima, cultura e irrigação foram utilizados como dados de entrada. Dois experimentos foram realizados em uma cobertura móvel composta por duas estruturas metálicas (16x10m) na cidade de Santa Maria, Rio Grande do Sul, Brasil, nas safras 2010/11 (segunda safra, época 1) e 2011/12 (primeira safra, época 2), sob sistema de plantio direto. As simulações mostraram que todas as estratégias de manejo de irrigação usadas na época 2 resultaram em déficit hídrico, enquanto que apenas duas estratégias apresentaram déficit na época 1 . Os resultados mostraram boa concordância entre os dados de água no solo observados e simulados, com um $R^{2}$ variando de 0.86 a 0.99 e raiz quadrada do erro médio variando de 2,7 a 5,6\% da água total disponível para as épocas 1 e 2, respectivamente. Os resultados observados do balanço hídrico mostraram que o milho cultivado na época 2 apresentou maior consumo de água em comparação com a época 1, devido à maior demanda atmosférica da época 2. O modelo SIMDualKc permitiu a partição da evapotranspiração da cultura em evaporação do solo e transpiração da cultura, demonstrando que o subperíodo de crescimento vegetativo apresentou as maiores diferenças entre as duas épocas em relação às demais fases de crescimento.

Palavras-chave: SIMDualKc, coeficiente dual, particionamento de evapotranspiração, evaporação do solo, transpiração da cultura.

\section{INTRODUCTION}

Maize (Zea mays L.) is the world's largest cultivated cereal and represents the food base of many countries (FAOSTAT, 2013). During 2015/16 crop season, Brazil cultivated approximately 15.215 million hectares, with a yield of 82,327 thousand tons (CONAB, 2016). In the State of Rio Grande 
do Sul, water availability is the factor that most affects maize yield, due to the irregular distribution of pluvial precipitation during the crop cycle, which may explain the yield fluctuations over the years (BERGAMASCHI et al., 2007).

Irrigation is among the viable alternatives for increasing productivity, by meeting the crop water requirements (PAREDES et al., 2014). The optimization of water use and productivity can be achieved through deficit irrigation (PEREIRA et al., 2012), which consists of applying depths lower than those needed to satisfy the full crop water requirements. Therefore, this may affect productivity, but reduces water and energy consumption. However, the yield reduction has to be minimal in order to maintain the economic return of the irrigated crop (RODRIGUES et al., 2013). The effects of water deficit on maize plants, when applied at various stages of crop development, are widely discussed in the literature (MARTINS et al., 2013, RODRIGUES et al., 2013).

Developing irrigation management strategies based on available soil water requires knowledge of plant response to water deficit, which can be obtained through modeling (PAREDES et al., 2014), relating grain yield or biomass production to evapotranspiration. The water balance models help to determine the irrigation needs and improve the management of the irrigation system (MA et al., 2013). The most common method for calculating crop water requirements is the $\mathrm{K}_{c}-\mathrm{ET}_{\mathrm{o}}$ method (ALLEN et al., 1998), which combines a crop coefficient $\left(\mathrm{K}_{\mathrm{c}}\right)$ with the grass reference evapotranspiration (ET) to estimate crop evapotranspiration $\left(\mathrm{ET}_{\mathrm{c}}\right)$. More recently, the dual $\mathrm{K}_{c}$ method was introduced and it provides a better estimation of daily $\mathrm{ET}_{\mathrm{c}}$, because it considers soil water evaporation $\left(\mathrm{E}_{\mathrm{s}}\right)$ and crop transpiration $\left(\mathrm{T}_{\mathrm{c}}\right)$ separately. The SIMDualKc model, developed by ROSA et al. (2012), uses the dual $\mathrm{K}_{\mathrm{c}}$ approach to provide information that helps irrigation management, especially in situations of water deficit.

The objectives of this study were: (i) to simulate the variation of the available soil water during the maize growth in two growing seasons in the Southern region of Brazil; (ii) to simulate and analyze the soil water balance and its components for irrigation strategies ranging from full to deficit and; (iii) to partition $\mathrm{ET}_{\mathrm{c}}$ into $\mathrm{E}_{\mathrm{s}}$ and $\mathrm{T}_{\mathrm{c}}$ using the SIMDualKc model.

\section{MATERIALS AND METHODS}

The experiments were conducted at the Universidade Federal de Santa Maria (UFSM), located in the State of Rio Grande do Sul (RS). The climate is humid subtropical (cfa), according to the Köppen-Gaiger classification (KOTTEK et al., 2006). The soil is classified as Ultisol (Soil Survey Staff, 2006), loamy in the top layers and clayey underneath.

Two experiments were carried out during 2010/11 and 2011/12 growing seasons. The first experiment was sown on January 13 ${ }^{\text {th }}, 2011$ (second crop, season 1), described by MARTINS et al. (2013), and the second was sown on October $15^{\mathrm{h}}, 2011$ (first crop, season 2), described in the study of GONZÁLEZ et al. (2015). Both experiments were conducted under a rainout shelter, composed of two $16 \times 10 \mathrm{~m}$ metallic structures, which move on rails in the East-West direction, as described by MARTINS et al. (2013).

The experiments consisted of four irrigation strategies, with four replications. During season 1, the treatments were: $100 \mathrm{~S} 1(100 \%$ of the accumulated $\mathrm{ET}_{\mathrm{c}}$ ), $81 \mathrm{~S} 1$ (mild deficit, $81 \%$ of the accumulated $\mathrm{ET}_{\mathrm{c}}$ ), $56 \mathrm{~S} 1$ (moderate deficit, $56 \%$ of the accumulated ET) and 29S1 (severe deficit, $29 \%$ of the accumulated $\mathrm{ET}_{\mathrm{c}}$ ). In this first season, depths of $25 \mathrm{~mm}$ were applied when the accumulated $\mathrm{ET}_{\mathrm{c}}$ values reached $25 \mathrm{~mm}(100 \%)$, $30 \mathrm{~mm}(81 \%), 36 \mathrm{~mm}(56 \%)$ and $43 \mathrm{~mm}$ (29\%). During season 2, the treatments were: $100 \mathrm{~S} 2(100 \%$ of the accumulated $\mathrm{ET}_{\mathrm{c}}$ ), $84 \mathrm{~S} 2$ (mild deficit, $84 \%$ of the accumulated $\mathrm{ET}_{\mathrm{c}}$ ), 59S2 (moderate deficit, $59 \%$ of the accumulated $\mathrm{ET}_{\mathrm{c}}$ ) and $30 \mathrm{~S} 2$ (severe deficit, $30 \%$ of the accumulated $\mathrm{ET}_{\mathrm{c}}$ ). In this season, irrigations were triggered when the accumulated $\mathrm{ET}_{\mathrm{c}}$ reached values of $25 \mathrm{~mm}(100 \%), 34 \mathrm{~mm}(84 \%) 40 \mathrm{~mm}(59 \%)$ and $43 \mathrm{~mm}(30 \%)$. Before implementing the treatments at 21 days after sowing (DAS), there were 73 and $95 \mathrm{~mm}$ of precipitation in seasons 1 and 2, respectively. On January 5, 2012 (season 2), an error in the irrigation system caused the application of a $108 \mathrm{~mm}$ irrigation depth in treatments 100S2 and 59S2.

The hybrid DKB240Y was sown on crop residues on the soil surface at the density of 6.5 plants $\mathrm{m}^{-2}$. A drip irrigation system was used, with selfcompensating dripping tubes (discharge of $1.3 \mathrm{~L} \mathrm{~h}^{-1}$ ). Soil moisture was measured using a set of FDR sensors (Campbell Scientific, Inc.), determining the volumetric soil water content in four layers of the soil profile $(0$ $10,10-25,25-55,55-85 \mathrm{~cm})$.

The soil water balance was simulated using the SIMDualKc model (ROSA et al., 2012) to calculate $E_{c}$ by separating it into $E_{s}$ and $T_{c}$. The input data of the model were: maximum and minimum air temperature $\left({ }^{\circ} \mathrm{C}\right)$, minimum relative air humidity $(\%)$ and $\mathrm{ET}_{\mathrm{o}}(\mathrm{mm})$, estimated by the FAOPenman-Monteith method (ALLEN et al., 1998) on a daily basis. The meteorological data were obtained 
from the automatic meteorological station located approximately 200 meters from the experimental area. The soil data used were field capacity, wilting point and soil texture. The irrigation data were composed of the irrigation system, fraction of soil wetted by irrigation (fw), irrigation dates and irrigation depths (mm). The crop data used were plant phenology, plant height (m), fraction of soil covered by crop (fc) and leaf area index (LAI), which were calibrated and validated as described by MARTINS et al. (2013) and GONZÁLEZ et al. (2015).

The SIMDualKc model input data also included the non-observed (standard) parameters such as the basal crop coefficient $\left(\mathrm{K}_{\mathrm{cb}}\right)$, depletion fraction for no stress (p), as well as parameters that characterize soil water evaporation, such as total evaporable water (TEW), readily evaporable water (REW), thickness of the evaporation soil layer $\left(Z_{e}\right)$, and parameters for estimating deep percolation $\left(a_{D}\right.$ and $b_{D}$ ). The SIMDualKc model uses a decay function of time (LIU et al., 2006) to estimate deep percolation, whose parameters were calibrated by MARTINS et al. (2013). Further details for the calibration and validation procedures of the SIMDualKc model can be found in ROSA et al. (2012), PAREDES et al. (2014) and PEREIRA et al. (2015).

In the simulation, the soil water content was converted to available soil water (ASW), which represents the water depth stored in the soil available to plants, above the permanent wilting point of the soil profile. The total available water (TAW) represents the upper limit of the ASW, i.e., it corresponds to the water stored at field capacity, throughout the root zone, while the fraction of readily available water (RAW) represents the lower limit of soil water availability, without causing water deficit $(\mathrm{RAW}=\mathrm{p}$.TAW $)$, where $\mathrm{p}$ is the water depth that indicates the threshold value, according to ALLEN et al. (1998). In this study, the $p$ value used was 0.5 .

The relationship between the observed and simulated data was evaluated through statistical indicators, such as regression coefficient $\left(b_{0}\right)$ forced to the origin and coefficient of determination $\left(\mathrm{R}^{2}\right)$. As proposed by MORIASI et al. (2007), the estimation of the residual errors was determined by the root mean square error (RMSE). The modelling efficiency (EF), proposed by NASH \& SUTCLIFFE (1970), was used to determine the relative magnitude of the residual variance compared to the variance of the observed data. These goodness-of-fit indicators are described by MARTINS et al. 2013 and GONZÁLEZ et al. 2015.

\section{RESULTS AND DISCUSSION}

In season 1, strategies $100 \mathrm{~S} 1$ and $81 \mathrm{~S} 1 \mathrm{did}$ not present water deficit during the crop growth cycle (Figure 1), since these treatments aimed to satisfy the water requirement of the crop. For strategy $56 \mathrm{~S} 1$, three periods of water deficit were observed: (i) from 76 to 79 days after sowing (DAS), the crop development stage (i.e. increased water demand); (ii) from 88 to 91 DAS, at the end of the midseason period; (iii) after 115 DAS, period of plant senescence or late season. Strategy 29S1 presented water deficit from 53 DAS until the end of the cycle, including flowering and grain filling, period of increased water demand and greater sensitivity to water deficit.

The variation of the ASW was higher in season 2 for all treatments (Table 1), and it is in accordance to the $\mathrm{ET}_{\mathrm{c} \text { act }}$ (actual evapotranspiration), which decreased proportionally to the increasing deficit, i.e., with the decrease in replenishment from 100 to $29 \%$. The runoff was insignificant and did not differ between the seasons, while deep percolation was higher in the treatment with the highest water replenishment, in both growing seasons.

For season 2, all the irrigation strategies presented some level of water deficit (Figure 1). In strategy $100 \mathrm{~S} 2$, there was slight water deficit (for a depletion factor of 0.5 ) starting at 110 DAS, after the beginning of plant senescence. In strategies 84S2, 59S2 and 30S2, the water deficit occurred from 98, 60 and 55 DAS, respectively, in the late (84S2) and midseason crop growth period; while the water deficit during the late season caused a small decrease in grain yield, in strategies 59S2 and 30S2 the deficit was much longer (from day 55 to harvest). Thus, root water extraction was severely affected, reducing $T_{c}$ in 22 and $59 \%$, respectively, in relation to the fully irrigated treatment, exhibiting differences in the grain yield, as shown in table 1.

In Southern Brazil, the sowing of maize in season 2 (considered the main growing season) occurs in a period where air temperatures and solar radiation progressively increase with the crop development, starting in October (SANGOI et al., 2010), causing a rapid increase in $\mathrm{ET}$. The development of the plants increases the LAI, increasing the transpiration requirement, associated with the increase in the evaporative demand of the atmosphere, resulting in a greater probability of occurrence of water deficit in the crop when grown under non-irrigated conditions (SERPA et al., 2012). On the other hand, sowing in January, as in season 1, the crop develops in a period in which the temperatures are lower, compared to 

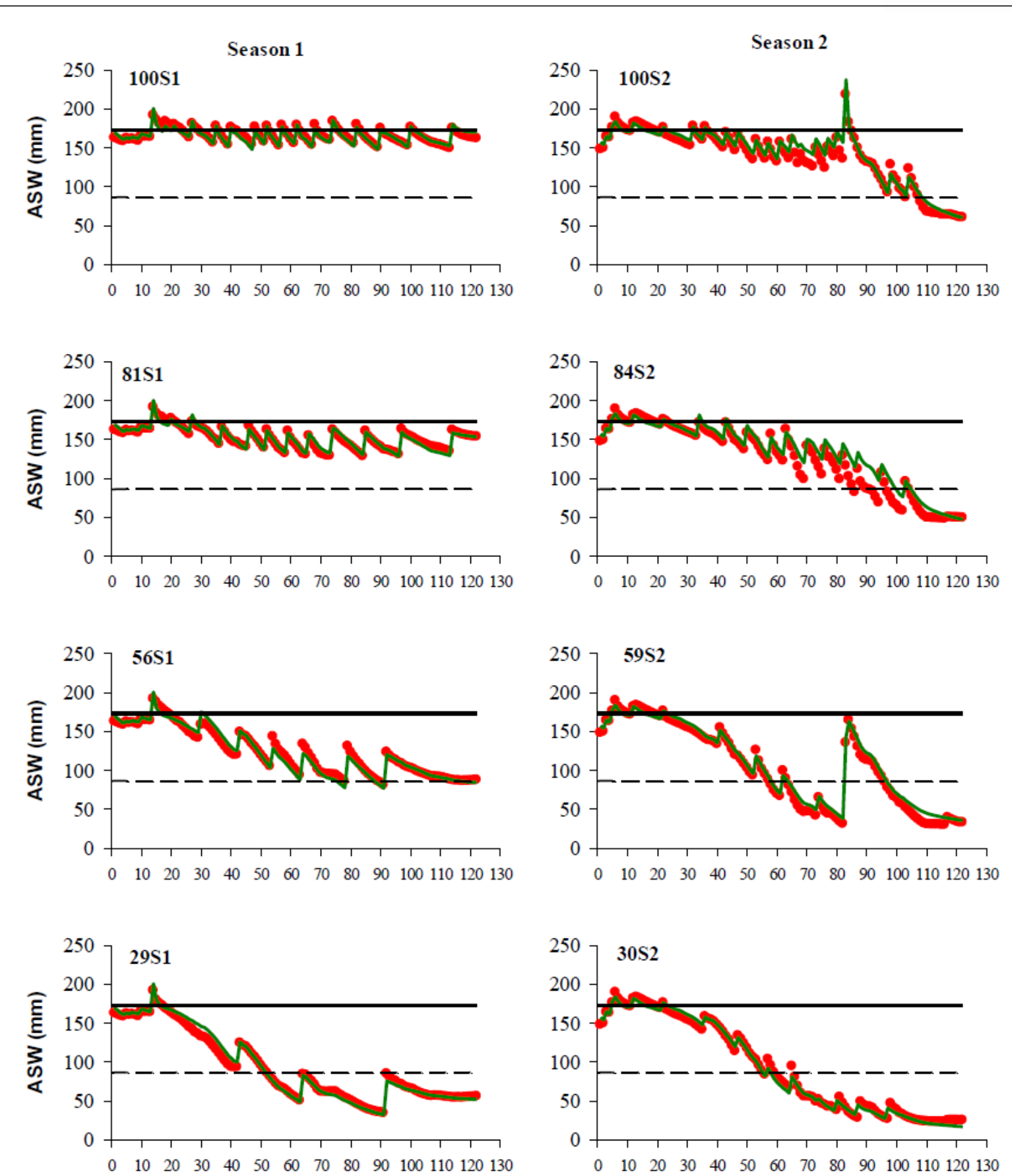

Days after sowing (DAS)

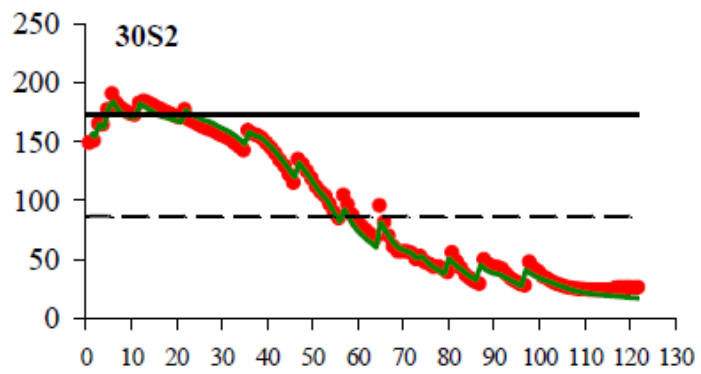

Days after sowing (DAS)

Figure 1 - Daily comparison between the observed $(\bullet)$ and simulated (-) data for available soil water (ASW) for 100S1, 81S1, 56S1 and 29S1 (season 1) and 100S2, 84S2, 59S2 and 30S2 (season 2). The horizontal lines refer to the total available water (TAW, -) and readily available water (RAW, - -).

season 2, reducing water consumption due to lower atmospheric demand, and thus the occurrence of water deficit is less probable. Short periods of water deficit at flowering and at the beginning of grain filling (midseason) cause greater variation in maize yield when these stages occur between December 
Table 1 - Components of the soil water balance, precipitation, irrigation, deep percolation, runoff, variation of soil water throughout the cycle, actual crop evapotranspiration; soil evaporation, crop transpiration and grain yield of maize grown in two seasons, season $1(2010 / 11)$ and season $2(2011 / 12)$, in Santa Maria, RS.

\begin{tabular}{|c|c|c|c|c|c|c|c|c|c|}
\hline $\mathrm{T}$ & $\mathrm{P}(\mathrm{mm})$ & $\mathrm{I}(\mathrm{mm})$ & $\mathrm{DP}(\mathrm{mm})$ & $\mathrm{RO}(\mathrm{mm})$ & $\Delta \mathrm{ASW}(\mathrm{mm})$ & $\mathrm{ET}_{\mathrm{c} \text { act }}(\mathrm{mm})$ & $\mathrm{Y}\left(\mathrm{kg} \mathrm{ha}^{-1}\right)$ & $\mathrm{E}_{\mathrm{s}}(\mathrm{mm})$ & $\mathrm{T}_{\mathrm{c}}(\mathrm{mm})$ \\
\hline \multicolumn{10}{|c|}{ 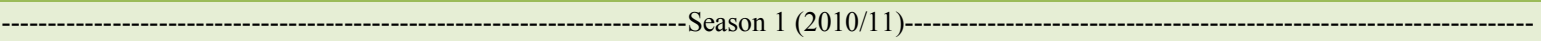 } \\
\hline $100 \mathrm{~S} 1$ & 73 & 389 & 86 & 1 & -3 & 364 & 9190 & 34 & 331 \\
\hline $81 \mathrm{~S} 1$ & 73 & 316 & 33 & 1 & -19 & 361 & 8340 & 31 & 330 \\
\hline $56 \mathrm{~S} 1$ & 73 & 218 & 24 & 1 & -89 & 341 & 7650 & 29 & 313 \\
\hline 29S1 & 73 & 113 & 23 & 1 & -122 & 270 & 5312 & 25 & 247 \\
\hline \multicolumn{10}{|c|}{ 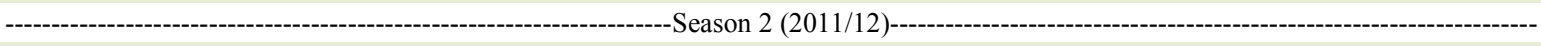 } \\
\hline $100 \mathrm{~S} 2$ & 95 & 412 & 83 & 0 & -98 & 522 & 8888 & 42 & 480 \\
\hline $84 \mathrm{~S} 2$ & 95 & 348 & 28 & 0 & -110 & 509 & 8455 & 38 & 470 \\
\hline $59 \mathrm{~S} 2$ & 95 & 243 & 39 & 0 & -122 & 419 & 6989 & 28 & 391 \\
\hline $30 \mathrm{~S} 2$ & 95 & 125 & 17 & 0 & -140 & 330 & 6174 & 29 & 301 \\
\hline
\end{tabular}

*100S1, 81S1, 56S1 and 29S1: different irrigation strategies applied to maize grown in season 1 (2010/11); 100S2, 84S2, 59S2 and 30S2: different irrigation strategies applied to maize grown in season $2(2011 / 12)$; $\mathrm{T}=$ Treatments; $\mathrm{P}=$ Precipitation $(\mathrm{mm})$; $\mathrm{I}=\mathrm{net}$ irrigation depth $(\mathrm{mm}) ; \mathrm{DP}=$ Deep Percolation $(\mathrm{mm}) ; \mathrm{RO}=$ runoff $(\mathrm{mm}) ; \Delta \mathrm{ASW}$ : variation of available soil water during the crop cycle (mm); $\mathrm{ET}_{\mathrm{c}}$

and January (BERGAMASCHI et al., 2013). The ET was lower in season 1 than in season 2, although no differences were observed in grain yield. PAYERO et al. (2006) found an excellent correlation between grain yield and $\mathrm{ET}_{\mathrm{c}}$ when there was no stress, but this relationship varied from year to year. For GRASSINI et al. (2009), high $\left(\approx 25^{\circ} \mathrm{C}\right)$ and low $\left(\approx<21^{\circ} \mathrm{C}\right)$ daily average temperatures at pollination and grain fill reduce grain yield, because of a reduction in the period of the grain fill and an increase in the respiratory rate (in the first case), and a reduction in the photosynthesis rate (in the second case). The observed differences in irrigation depths and $\mathrm{ET}_{\mathrm{c}}$ as well as the yield response in the two growing seasons are related to the different meteorological conditions observed during the periods.

It was found good accuracy of the SIMDualKc model for both seasons (Table 2), since the $\mathrm{b}_{0}$ was close to 1.0 for all the treatments, which means that the ASW simulated by the model corresponds well to the soil water observations. The $\mathrm{R}^{2}$ ranged from 0.86 to 0.99 for season 1 , and from 0.97 to 0.99 for season 2 , indicating that most of the observed variations can be explained by the SIMDualKc model. The estimation errors were relatively low, with a mean RMSE of $4.5 \mathrm{~mm}$ for season 1 and $9.1 \mathrm{~mm}$ for season 2 for all the strategies, which represents $2.7 \%$ and $5.6 \%$ of the TAW, respectively. The EF ranged from 0.85 to 0.99 (season 1), and from 0.94 to 0.99 (season 2), demonstrating that the magnitude of the residual variance is comparable to that of the measured data variance.
Analyzing the water balance components generated by SIMDualKc for the two growing seasons (Table 1), it was observed a $71 \%$ reduction in the total amount of water applied from 100S1 to 29S1 in season 1, due to the increased severity of the deficit applied, while the total reduction in $\mathrm{ET}_{\mathrm{c} \text { act }}$ was only $25 \%$ (from 364 to $270 \mathrm{~mm}$ ), and the reduction in yield was $42.2 \%$. The lowest reduction in water consumption $\left(\mathrm{ET}_{\mathrm{c} \text { act }}\right)$ in relation to the amount of water applied was a result of the water depth stored

Table 2 - Goodness-of-fit relative to the model simulation of soil water content for the irrigation treatments using the calibrated parameters, for Season 1 (2010/2011) and Season $2(2011 / 2012)$.

\begin{tabular}{|c|c|c|c|c|}
\hline & $\mathrm{b}$ & $\mathrm{R}^{2}$ & RMSE (mm) & $\mathrm{EF}$ \\
\hline \multicolumn{5}{|c|}{---------------------------Season 1 (2010/11)-----------------------. } \\
\hline $100 \mathrm{~S} 1$ & 1.00 & 0.97 & 5.5 & 0.97 \\
\hline $81 \mathrm{~S} 1$ & 1.00 & 0.86 & 3.4 & 0.85 \\
\hline $56 \mathrm{~S} 1$ & 1.00 & 0.93 & 3.6 & 0.93 \\
\hline $30 \mathrm{~S} 1$ & 1.02 & 0.99 & 5 & 0.99 \\
\hline \multicolumn{5}{|c|}{ 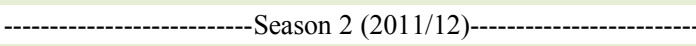 } \\
\hline $100 \mathrm{~S} 2$ & 1.04 & 0.99 & 7.3 & 0.97 \\
\hline $84 \mathrm{~S} 2$ & 1.06 & 0.97 & 12.4 & 0.94 \\
\hline 59S2 & 1.06 & 0.99 & 9.9 & 0.97 \\
\hline $30 \mathrm{~S} 2$ & 1.03 & 0.99 & 6.8 & 0.99 \\
\hline
\end{tabular}

${ }^{*} \mathrm{~b}$ and $\mathrm{R}^{2}$ are the coefficients of regression and determination; RMSE is the root mean square error; EF is the modelling efficiency. 
in the soil (ASW) at the initial crop growth stage (approximately $160 \mathrm{~mm}$ ). There was a reduction of $70 \%$ in the total irrigated depth (Table 1) from 100S2 to $30 \mathrm{~S} 2$, reducing the $\mathrm{ET}_{\mathrm{c} \text { act }}$ by $37 \%$ and yield by $30.5 \%$. These differences were caused by the greater use of the ASW by the stress-free crop (Table 1), as the ASW was close to the TAW during the cycle in the stress-free treatments (Figure 1).

A linear relationship was observed between the cumulative irrigated depths and grain yield, as well as between the applied depths and $\mathrm{ET}_{\mathrm{c}}$, for the two growing seasons. This corroborates with the observations of GIMÉNEZ et al. (2016), who found an increase in grain yield and water use efficiency with increased $\mathrm{ET}_{\mathrm{c}^{\prime}}$ Grain yields were significantly affected by irrigation management, so that the less water applied, the lower the grain yield. For season 1, treatments 81S1, $56 \mathrm{~S} 1$ and $29 \mathrm{~S} 1$ presented a reduction of $9.3 \%, 16.8 \%$ and $42.2 \%$ in yield, respectively, compared to $100 \mathrm{~S} 1$. For season 2, grain yield reduced in $44 \%$ from the most irrigated to the least irrigated treatment, while the difference between the largest and the smallest depth between these two treatments (100S2 and 30S2) was of $287 \mathrm{~mm}$. For season 1, the reduction in grain yield between 100S1 and 29S1 was more significant (73\%) for a smaller variation in the total water that entered the system $(276 \mathrm{~mm})$. The lower response of the crop to the application of water in season 2 may have been caused by the accidental entry of an unwarranted water depth on January 5, 2012. The $\mathrm{ET}_{\mathrm{c} \text { act }}$ was lower in the strategies that received less water (30S2 and 29S1), which resulted in lower grain yield in season $1\left(5312 \mathrm{~kg} \mathrm{ha}^{-1}\right)$ compared to season $2\left(6174 \mathrm{~kg} \mathrm{ha}^{-1}\right)$.

Considering the partitioning of $\mathrm{ET}_{\mathrm{c} \text { act }}$ for both seasons, $E_{s}$ was slightly higher than $T_{c}$ (Table 1 ) at the initial stage of plant development, due to the lower LAI and lower fc (ALLEN et al., 1998). $T_{c}$ increased linearly with the increase in plant height and LAI, reaching maximum values in the subperiod of flowering-grain fill, stage of greater transpiration capacity of plants. However, $\mathrm{E}_{\mathrm{s}}$ was higher in season 2 compared to season 1, representing 1.1 and $0.28 \%$ (on average) of the $\mathrm{ET}_{\mathrm{c}}$ of this stage for seasons 2 and 1 , respectively. This was as a result of the greater availability of energy for evaporation, and its reduction in season 1. Both $E_{s}$ and $T_{c}$ were higher in season 2 in comparison to season 1. Both $\mathrm{E}_{\mathrm{s}}$ and $\mathrm{E}_{\mathrm{s}} / \mathrm{T}_{\mathrm{c}}$ were slightly higher in season 1 than in season 2 (Table 1), observing a reduction in $\mathrm{E}_{\mathrm{s}}$ in strategies with water deficit, due to the less frequent irrigation application. The values of $\mathrm{E}_{\mathrm{s}} / \mathrm{T}_{\mathrm{c}}$ are lower than those reported in the literature (PAREDES et al., 2014; GRASSINI et al., 2009). This can be attributed to the presence of crop residues on the soil surface and to drip irrigation, which provides the partial moistening of the soil.

\section{CONCLUSION}

The soil water balance components showed that maize grown in season 2 presented crop evapotranspiration (ET) 24\% higher than in season 1. This shows the greater susceptibility of the maize crop in season 2 to water deficit, due to the higher consumption of water by the plants in that period, which was on average $111 \mathrm{~mm}$ higher than season 1 .

Respect the partitioning of $\mathrm{ET}_{\mathrm{c}}$ into soil evaporation $\left(\mathrm{E}_{\mathrm{s}}\right)$ and crop transpiration $\left(\mathrm{T}_{\mathrm{c}}^{\mathrm{c}}\right)$, it was found that the subperiod of vegetative development was the one that presented the greatest differences between the two seasons, and $\mathrm{E}_{\mathrm{s}}$ and $\mathrm{T}_{\mathrm{c}}$ were 63.4 and $54.5 \%$ higher in season 2 compared to season 1 for this subperiod, respectively.

\section{ACKNOWLEDGEMENTS}

This study was funded by the Project Fundação para a Ciência e a Tecnologia (FCT), Coordenação de Aperfeiçoamento de Pessoal de Nível Superior (CAPES) - 2011/2012, Proc. ${ }^{\circ 314 / 2011}$ a Brazil and Portugal bilateral cooperation project funded by Coordenação de Aperfeiçoamento de Pessoal de Nível Superior (CAPES), Brazil, and Fundação para a Ciência e a Tecnologia (FCT), Portugal. Scholarships provided to J. A. Martins, by Coordenação de Aperfeiçoamento de Pessoal de Nível Superior (CAPES), to G. C. Rodrigues and P. Paredes, by Fundação para a Ciência e a Tecnologia (FCT), and to A. E. Knies and Z. B. de Oliveira, by Conselho Nacional de Desenvolvimento Científico e Tecnológico (CNPq), Brasil, are acknowledged.

\section{REFERENCES}

ALLEN, R. G. et al. Crop evapotranspiration. Guidelines for computing crop water requirements. FAO irrigation and drainage paper 56, 1998. Rome, Italy: FAO, 300 pp. Available from: $<$ http:// www.fao.org/docrep/X0490E/X0490E00.htm>. Accessed: Apr. 06, 2016. doi: ISBN 92-5-104219-5.

BERGAMASCHI, H. etal. Maize yield and rainfall on different spatial and temporal scales in Southern Brazil. Pesquisa Agropecuária Brasileira, v.42, n.5, p.603 - 613, 2007. Available from: <http://www.scielo.br/scielo. php?script=sci_arttext\&pid=S0100-204X2007000500001>. Accessed: Apr. 06, 2016. doi: 10.1590/S0100-204X2007000500001.

BERGAMASCHI, H. et al. Simulating maize yield in sub-tropical conditions of Southern Brazil using Glam model. Pesquisa Agropecuária Brasileira, v.48, n.2, p.132-140, 2013. Available from: $<$ http://www.scielo.br/scielo.php?script=sci_arttext\&pid=S0100204X2013000200002>. Accessed: Apr. 06, 2016. doi: 10.1590/ S0100-204X2013000200002.

CONAB. Acompanhamento da safra 2015/2016 brasileira. 2016. Available from: $<$ http://www.conab.gov.br/conteudos.php?a=1253> . Accessed: Apr. 06, 2016.

FAOSTAT - FOOD AND AGRICULTURE ORGANIZATION OF THE UNITED NATIONS STATISTICS. Produção nos principais países produtores de milho. 2013. Available from: <http://www. faostat.fao.org.>. Accessed: Apr. 06, 2016. 
GIMÉNEZ, L. et al. Predicting maize transpiration, water use and productivity for developing improved supplemental irrigation schedules in Western Uruguay to cope with climate variability. Water. 2016, 8, 309. Available from: <http://cel.webofknowledge. com $/$ InboundService.do? mode $=$ FullRecord\&customersID $=$ ORCID $\&$ IsProductCode $=$ Yes \& product $=$ CEL \& KeyUID $=$ WOS $\% 3$ A00038 $0764800042 \&$ Init $=$ Yes $\&$ Func $=$ Frame $\&$ action $=$ retrieve $\&$ Src App $=O$ rcidOrg\&SrcAuth=ORCID\&SID=2C5W8S4oU4nfZWRV7HM\&U $\mathrm{T}=\mathrm{WOS} \% 3 \mathrm{~A} 0003807648000423>$. Accessed: Aug. 06, 2017. doi: $10.3390 /$ w8070309.

GONZÁLEZ, M. G. et al. Modelling soil water dynamics of full and deficit drip irrigated maize cultivated under a rain shelter. Biosystems Engineering, v.132, p.1 - 8, 2015. Available from: <http://www. sciencedirect.com/science/article/pii/S1537511015000203>. Accessed: Apr. 06, 2016. doi: 10.1016/j.biosystemseng.2015.02.001.

GRASSINI, P. et al. 2009. Limits to maize productivity in Western Corn-Belt: A simulation analysis for fully irrigated and rainfed conditions. Agricultural and Forest Meteorology, v.149, p.1254 1265, 2009. Available from: <http://digitalcommons.unl.edu/ cgi/viewcontent.cgi? article $=1312 \&$ context $=$ agronomyfacpub $>$. Accessed: Apr. 06, 2016. doi: 10.1016/j.agrformet.2009.02.012.

KOTTEK, M., J. et al. World Map of the Köppen-Geiger climate classification updated. Meteorol.Z., v.15, p.259-263, 2006. Available from: <http://koeppen-geiger.vu-wien.ac.at/pdf/Paper_2006.pdf $>$. Accessed: Apr. 06, 2016. doi: 10.1127/0941-2948/2006/0130.

MA, Y. et al. A root zone model for estimating soil water balance and crop yield responses to deficit irrigation in the North China Plain. Agricultural Water Management, v.27, p.13-24, 2013. Available from: <http://adsabs.harvard.edu/abs/2012AGUFM.H53C1542M>. Accessed: Apr. 06, 2016. doi: 10.1016/j.agwat.2013.05.011.

MARTINS, J. D. et al. Dual crop coefficients for maize in southern Brazil: model testing for sprinkler and drip irrigation and mulched soil. Biosystems Engineering, v.115, p.291-310, 2013. Available from: $<$ http://www.sciencedirect.com/science/article/pii/ S1537511013000627>. Accessed: Apr. 06, 2016. doi: 10.1016/j. biosystemseng.2013.03.016.

MORIASI, D. N. et al. Model evaluation guidelines for systematic quantification of accuracy in watershed simulations. Transactions of the ASABE, v.50, n.3, p.885-900, 2007. Available from: <http:// citeseerx.ist.psu.edu/viewdoc/download?doi=10.1.1.532.2506\&rep $=$ rep1\&type=pdf $>$. Accessed: Apr. 06, 2016. doi: ISSN 0001-2351.

NASH, J.E., SUTCLIFFE, J.V. River flow forecasting through conceptual models: part 1. A discussion of principles. Journal of Hydrology, v.10, n.3, p.282-290, 1970. Available from: <http:// www.sciencedirect.com/science/article/pii/0022169470902556>. Accessed: Apr. 06, 2016. doi: 10.1016/0022-1694(70)90255-6.

PAREDES, P. et al. Partitioning evapotranspiration, yield prediction and economic returns of maize under various irrigation management strategies. Agricultural Water Management, v.135, p.27-39, 2014. Available from: <http://www.sciencedirect.com/ science/article/pii/S0378377413003521>. Accessed: Apr. 06, 2016. doi: 10.1016/j.agwat.2013.12.010.

PAYERO, J. O. et al. Yield response of corn to deficit irrigation in a semiarid climate. Agricultural Water Management, v.84, p. 101-112, 2006. Available from: <http://www.sciencedirect. com/science/article/pii/S0378377406000278>. Accessed: Apr. 06 , 2016. doi: 10.1016/j.agwat.2006.01.009.

PEREIRA, L.S. et al. Improved indicators of water use performance and productivity for sustainable water conservation and saving. Agricultural Water Management, v.108, p.39-51, 2012. Available from: <http://www.sciencedirect.com/science/ article/pii/S0378377411002290>. Accessed: Apr. 06, 2016. doi: 10.1016/j.agwat.2011.08.022.

PEREIRA, L.S. et al. Modeling barley water use and evapotranspiration partitioning in two contrasting rainfall years. Assessing SIMDualKc and AquaCrop models. Agricultural Water Management, v.159, p.239-254, 2015. Available from: <http://www.sciencedirect.com/science/ article/pii/S0378377415300238>. Accessed: Apr. 06, 2016. doi: 10.1016/j.agwat.2015.06.006.

RODRIGUES, G.C. et al. Comparing sprinkler and drip irrigation systems for full and deficit irrigated maize using multicriteria analysis and simulation modeling: ranking for water saving vs farm economic returns. Agricultural Water Management, v.126, p.85-96, 2013. Available from: <http://www.sciencedirect. com/science/article/pii/S0378377413001169>. Accessed: Apr. 06, 2016. doi: 10.1016/j.agwat.2013.05.005.

ROSA, R. D. et al. Implementing the dual crop coefficient approach in interactive software. 1. Background and computational strategy. Agricultural Water Management, v.103, p.8-12 2012. Available from: $<$ http://www.sciencedirect.com/science/article/pii/ S037837741100285X>. Accessed: Apr. 06, 2016. doi: 10.1016/j. agwat.2011.10.013.

SANGOI, L. et al. Ecofisiologia da cultura do milho para altos rendimentos. Lages: Graphel, 87p, 2010.

SERPA, M. DA S. et al. Densidade de plantas em híbridos de milho semeados no final do inverno em ambientes irrigados e de sequeiro. Pesquisa Agropecuária Brasileira, Brasília, v.47, n.4, p.541-549, abr. 2012. Available from: <http://www.scielo.br/pdf/ pab/v47n4/47n04a10.pdf>. Accessed: Apr. 06, 2016. doi: 10.1590/ S0100-204X2012000400010.

SOIL SURVEY STAFF. Keys to soil taxonomy (10th ed.) Washington, DC: Natural Resources Conservation Service, United States Department of Agriculture. 2006. Available from: $<$ https://www.nrcs.usda.gov/Internet/FSE DOCUMENTS/ nrcs142p2_052172.pdf>. Accessed: Apr. 06, 2016. 